\title{
Crocin Reduces Oxidative Stress Produced by Busulfan Administration on Fertility of Male Rats
}

\author{
Shiva Roshankhah ${ }^{1}$, Amir Abdolmaleki ${ }^{1}$ (D), Cyrus Jalili ${ }^{2}$ iD, Mohammad Reza Salahshoor ${ }^{*}$ (iD
}

1. Dept. of Anatomical Sciences, School of Medicine, Kermanshah University of Medical Sciences, Kermanshah, Iran

2. Medical Biology Research Center, Kermanshah University of Medical Sciences, Kermanshah, Iran

\begin{tabular}{|c|c|}
\hline Article Info & ABSTRACT \\
\hline doi $10.30699 / j a m b s .27 .125 .25$ & \multirow{4}{*}{$\begin{array}{l}\text { Background \& Objective: Busulfan (BUS) as a drug for cancer treatment can } \\
\text { produce free radicals. Crocin (CRO) is a potent antioxidant with beneficial effects. } \\
\text { This study was designed to evaluate the effects of CRO against BUS-related damages } \\
\text { to the male rats reproductive parameters. } \\
\text { Materials \& Methods: Forty-eight male rats were randomly assigned into } 8 \text { groups; } \\
\text { Group } 1 \text { (normal control group) received normal saline; Group } 2 \text { (BUS control group) } \\
\text { received } 10 \mathrm{mg} / \mathrm{kg} / \text { /body weight (b.w.) of BUS; Group 3-5 (CRO groups) received } 12.5 \text {, } \\
25.0,50.0 \mathrm{mg} / \mathrm{kg} / \mathrm{b} \text {.w. of CRO, respectively; Group 6-8 (BUS + CRO groups) received } \\
\text { BUS + CRO. Treatments were administered daily by intraperitoneal injection in a five- } \\
\text { week period. The sperm parameters, testis malondialdehyde (MDA), total antioxidant } \\
\text { capacity (TAC), testosterone level, and germinal layer height were evaluated } \\
\text { histologically and analyzed statistically. }\end{array}$} \\
\hline $\begin{array}{l}\text { Received: } 2019 / 08 / 02 \\
\text { Accepted: } 2019 / 08 / 10\end{array}$ & \\
\hline Published Online: 20 Sep 2019; & \\
\hline \multirow{2}{*}{ 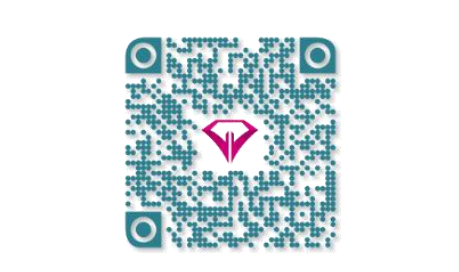 } & \\
\hline & $\begin{array}{l}\text { Results: All parameters reduced significantly in the BUS control group compared to } \\
\text { the normal control group }(P<0.01) \text { except the MDA level (which increased). The CRO } \\
\text { and CRO + BUS treatments in all doses increased whole parameters significantly }\end{array}$ \\
\hline \multirow{3}{*}{$\begin{array}{l}\text { Corresponding Information: } \\
\text { Mohammad Reza Salahshoor, Dept. of } \\
\text { Anatomical Sciences, School of Medicine, } \\
\text { Kermanshah University of Medical Sciences, } \\
\text { Kermanshah, Iran } \\
\text { E-Mail: reza.salahshoor@yahoo.com }\end{array}$} & $\begin{array}{l}\text { significant modifications were observed in all CRO groups compared to the normal } \\
\text { control group }(P>0.05) \text {. }\end{array}$ \\
\hline & $\begin{array}{l}\text { Conclusion: It seems that CRO could increase the quality of spermatozoa and } \\
\text { improves BUS -induced adverse effects on male fertility parameters. }\end{array}$ \\
\hline & Keywords: Busulfan, Crocin, Fertility \\
\hline & \\
\hline
\end{tabular}

\section{Introduction}

Chemotherapy is a common way of cancer treatment. Chemotherapy drugs, in addition to their suppressive effects on cancer cell activity, can also affect healthy cells like spermatogenic lineage leading to male infertility (1). BUS as a DNA-destructive chemotherapy agent is used in two forms of doses; low doses for long-term treatment of chronic myelogenous leukemia and ovarian cancers, and high doses for treatment of bone marrow suppression in patients under bone marrow transplantation (2). BUS has inhibitory effects on cell division with a high proliferation rate on spermatogonial cells (3). BUS also causes chromosomal anomalies and lethal mutations, mostly in sperms (4). Dehghani et al. (5) reported that the consumption of BUS induces gonadal dysfunction and reduces somatic and testicular germinal cells in rats. Spermatogenesis disruption following the administration of BUS seems to be associated with distructive nature and its significant effects on spermatogonial stem cells (6). Application of BUS as a proper pharmaceutical method to evacuate seminiferous tubules has long been taken into consideration to study the performance of germinal stem cells (7). The BUS based on free radical production can induce cell death through (8) impairment lipids, proteins, and nucleic acids of cells (9). The accumulation of free radicals in the cell decreases activity of antioxidant enzymes, increases reactive oxygen species (ROS) level and induces lipid oxidation (10). This phenomenon, in turn, causes DNA breakdown and inactivation of specific proteins, and thus loss of biologic cell membranes (11). Crocus satious $\mathrm{L}$. is one of the expensive and valuable plants cultivated all over the world (12). The value of Crocus satious L. returns to its primary metabolite, the CRO, as well as its derivatives that are responsible for its red appearance (13). So far, numerous therapeutic effects of Crocus satious L. have been reported, most of which are attributed to its antioxidant and anti-inflammatory properties (14). In a study of Colapietro et al. (15) about 
CRO inhibitory effects on cancerogenesis, it was concluded that this agent could act as an activator of DNA repair enzymes to prevent DNA damage. As a potent antioxidant, the $\mathrm{CRO}$ can eliminate free radicals (16). Due to its antioxidant properties, CRO is used to preserve sperms in low temperatures (17). The results of Roshankhah et al. (18) showed that sperm parameters were significantly improved in CRO treatment groups. Considering the antioxidant properties of CRO, this material seems to have protective effects on male reproductive parameters against BUS-induced oxidative stress. Thus, this study aimed to evaluate the impacts of CRO against damage to the male rats' reproductive parameters induced by BUS.

\section{Materials and Methods}

\section{Preparation of Chemicals and Measuring Kits}

BUS and CRO were bought from Merck Co. (Germany). Ether, formalin, sodium acetate, ferric chloride, iron sulfate, hematoxylin and eosin (H\&E), and zinc sulfate powder were purchased from Sigma Co. (USA). For biochemical analysis, the Commercial Pars Azmun colorimetric kits (Pars Azmun, TehranIran) were obtained from Pars Azmoon Co. (I.R. Iran). All other buffer additives and solvents were obtained from Merck Co. (Germany). For preparation of 12.5 $\mathrm{mg} / \mathrm{kg}$ body weight (b.w.) of CRO, $1.5 \mathrm{mg}$ of powder of CRO was dissolved in $1.2 \mathrm{~mL}$ of normal saline $(0.9 \%)$, and was passed through a $0.45-\mathrm{mm}$ pore size filter (Lida Manufacturing, Kenosha, Wis. USA), and finally each rat received $12.5 \mathrm{mg} / \mathrm{kg}$ of this solution intraperitoneally in treatment groups of 3 and 6 . The other doses of CRO $(25.0 \mathrm{mg} / \mathrm{kg} \mathrm{b.w}$. and $50 \mathrm{mg} / \mathrm{kg}$ b.w.) were made exactly the same way. For $10.0 \mathrm{mg} / \mathrm{kg}$ BUS preparation, $40.5 \mathrm{mg}$ of BUS was dissolved in 6.0 $\mathrm{mL}$ of saline, and each rat in groups of $2,6,7$, and 8 received $10.0 \mathrm{mg} / \mathrm{kg}$ of the solution through intraperitoneal injection. (These values were calculated for 1 group, and each group had six rats).

\section{Animals}

The present experimental study was carried out in the Anatomy Department of Kermanshah University of Medical Sciences from May 2018 to December 2018. This study was done on 48 male Wistar rats (8 weeks, 220-250 g) at Kermanshah University of Medical Sciences. The rats were maintained in animal home of Medical School of Kermanshah University of Medical Sciences with following environmental conditions; regular diet with water ad libitum, 12:12 h light/dark cycle, $23 \pm 2{ }^{\circ} \mathrm{C}$ environment temperature, relative humidity of $50 \% \pm 5 \%$. All animals were adapted in a 1week period prior to the experiments (18). The study was applied due to the Institutional Animal Ethics Committee, Research Deputy in Kermanshah University of Medical Sciences, Kermanshah, Iran (ethic approval number: IR.KUMS.REC.1397.305).

\section{Study Groups and Treatment of Animals}

Forty-eight rats were grouped into 8 groups ( 6 rats in each); first group (normal control group) received intraperitoneal (i.p.) injection of normal saline (0.9\%). The second group (BUS control group) received 10 $\mathrm{mg} / \mathrm{kg} / \mathrm{b}$.w. of BUS (i.p.) for 5 weeks at 9:45 AM (3). The third to fifth groups (CRO administration groups) received CRO (i.p.) at the doses of 12.5, 25.0, and 50.0 $\mathrm{mg} / \mathrm{kg} / \mathrm{b}$.w. for 5 weeks at 10:00 AM, respectively. The sixth to eighth groups (CRO + BUS administration groups) first received BUS (a single i.p. injection with a dose of $10 \mathrm{mg} / \mathrm{kg} / \mathrm{b} . \mathrm{w}$.) to induce damage to sexual parameters, then received various doses of CRO including 12.5, 25.0 and $50.0 \mathrm{mg} / \mathrm{kg} / \mathrm{b}$.w. (i.p.) for 5 weeks at 10:00 AM, respectively $(3,18)$.

\section{Animals' Dissection and Sampling}

The rats were anesthetized by ketamine hydrochloride $(100 \mathrm{mg} / \mathrm{kg}$, i.p) and xylazine (10 $\mathrm{mg} / \mathrm{kg}$ ). Blood sample ( $3 \mathrm{~mL}$ ) was taken from the heart by subxiphoid approach. The samples were incubated $\left(37^{\circ} \mathrm{C}, 10 \mathrm{~min}\right)$ and centrifuged $(255 \mathrm{~g}, 10 \mathrm{~min})$. The obtained serum was isolated at $-80^{\circ} \mathrm{C}$ for biochemical assessments. Following abdominal incision, the epididymis tail was separated from the testes and placed in Nutrient Mixture F-12/ fetal bovine serum $5 \%$ culture medium. The left removed testis was fixed in a $10 \%$ formalin solution for histological and morphometrical examinations, and the right one was also dissected for the malondialdehyde (MDA) level estimations (10).

\section{Sperm Cells Collection}

In warmed $\left(37^{\circ} \mathrm{C}\right)$ solution containing $10 \mathrm{~mL}$ of Hank's balanced salt, both cauda epididymides were cut, and the spermatozoa dispersed into the buffer. Fifteen minutes later, the cauda was removed, and the suspension was slightly shaken to be normalized. It then was observed by a light microscope with magnification of $400 \times(18)$.

\section{Progressive Motility}

Sperm motility was studied based on World Health Organization protocols. Four levels of criteria were considered; (a) direct way with fast progressive motility, (b) direct or indirect way with slow progressive motility, (c) no progressive motility, and (d) no motility. As the quick progressive motility is critically involved in fertility than others, this kind of motility is considered in this study. The progressive motility was analyzed by an optical microscope (40x) in 20 fields of view. $100 \mu \mathrm{L}$ of semen sample was placed on a sterilized slide culture. The slide culture was placed on it and examined by a microscope (Olympus Co., Tokyo, Japan) at 400× magnification. About 200 sperm cells in each sample were counted using a cell count device. In whole treated and nontreated groups, the assessment of sperm parameters was done by two qualified experts to minimize the observer subjectivity or bias (11). 


\section{Sperm Viability}

Eosin staining was used to identify the living sperm cells from dead ones. The basis of this technique returned to the absorption of stain by membrane of dead cells and disposal by other living cells. Twenty minutes later, $10 \mu \mathrm{L}$ of the medium was mixed with an equal volume of eosin. 5 to $10 \mathrm{~min}$ later, the mixture was transferred on a neobar lam. Living sperms lacked stain, and dead sperms became pink. The prepared slide culture was examined (40x). At least 100 sperms were calculated from each random sample from the 10 fields, and the percentage of live sperm cells was documented (12).

\section{Sperm Cells Morphology}

The normal sperm cell morphology was assessed through the examination of sperm smears from the right cauda epididymis. To analyze the cell malformation, an aliquot of the sample along with a drop of Eosin/nigrosine staining was removed. The slides were then observed by a light microscope $(400 \times)$. A total of 400 spermatozoa were studied on the respective slide (4000 cells in each group) for assessment of the head and tail irregularities (18).

\section{Sperm Count Calculation}

$500 \mu \mathrm{L}$ of the cell suspension was diluted in formaldehyde fixative (Sigma; USA). Sperm suspension $(20 \mu \mathrm{L})$ was removed from the previous diluted solution and moved to a hemocytometer located in a Petri dish (for $10 \mathrm{~min}$ ). This procedure was done with a dampened filter paper. The stable cells were counted per 300 small squares of the hemocytometer (40x). The cell number per $\mathrm{mm}^{3}$ was calculated as following formula: number of sperm counted $\times$ dilution/number counted $\left(\mathrm{mm}^{2}\right) \times$ depth of wall (10).

\section{Tissue Preparing and Staining for Evaluation of Germinal Layer of Seminiferous Tubules}

Non-parenchymal tissues (fat, fascia, and vessels) of removed left testis were dissected, and paraffinembedded blocks were prepared using Automatic Tissue Processor including; fixation with $10 \%$ formal saline (for $72 \mathrm{~h}$ ), washing in running water, dehydration by ethanol ( $50 \%-100 \%$ concentrations), clearing by xylene, and soft paraffin infiltration. $5-\mu \mathrm{m}$ slices were cut by a microtome (Leica RM 2125, Leica Microsystems Nussloch GmbH; Germany), and 5 sections per paraffin blocks were selected and stained by hematoxylin and eosin. Finally, the histological slides were assessed by an Olympus BX-38F02 microscope using Olysia-software (Olympus Optical. Tokyo, Japan) (12).

\section{Testosterone Level}

The collected blood sample was centrifuged $(5000 \mathrm{~g}$, $23^{\circ} \mathrm{C}, 15 \mathrm{~min}$ ), and the serum was preserved in freezer $\left(-180^{\circ} \mathrm{C}\right)$. The serum testosterone level was examined by enzyme-linked immunosorbent assay (Abcam 108666, USA) (11).

\section{Measurement of Testis MDA}

MDA levels as lipid peroxidation criteria were considered. Homogenized samples were prepared by centrifugation $(1500 \mathrm{~g}, 10 \mathrm{~min})$ in $1.15 \%$ potassium chloride. The homogenated subjects were mixed with a reaction mixture containing sodium dodecyl sulfate, acetic acid (pH 3.5), thiobarbituric acid, and distilled water. Following boiling $\left(60 \mathrm{~min}, 96^{\circ} \mathrm{C}\right)$ and centrifuging ( $3000 \mathrm{~g}, 10 \mathrm{~min}$ ), the absorbency of the supernatant was measured at $550 \mathrm{~nm}$ (19).

\section{Estimation of TAC Level}

The TAC level was measured based on oxidation colorimetry resuscitation using an acquisition kit (Cat No: TAC-96B) ZellBioGmbH-Germany. The kit contained one reagent ready to use, buffer (100X), dye powder, reaction suspension solution, standard, and a microplate of 96 wells. In this assay, the TAC was equivalent to some antioxidants in the sample in comparison with ascorbic acid as standard. The kit's sensitivity was equal to $0.1 \mathrm{mM}$ and the final absorbance was read at $490 \mathrm{~nm}$ and unit conversion was performed (19).

\section{Statistical Analysis}

The Kolmogorov-Smirnov test was done using SPSS, v20 (SPSS Inc., Chicago, Ill., USA) to investigate the standard distribution. The data were analyzed using one-way followed by Tukey post-hoc test. $P<0.05$ was considered as significant and the variables were represented as mean $\pm \mathrm{SD}$.

\section{Results}

\section{Progressive Sperm Motility, Count and Viability}

BUS caused a significant reduction in sperm viability, count, and progressive motility compared to the normal control group $(P<0.01)$. No significant variations were detected in the CRO groups in comparison with the normal control group $(P>0.05)$. Also, sperm cell viability, count and progressive motility in all treated CRO and BUS+CRO groups improved significantly compared to the BUS group $(P<0.01)($ Table 1)

\section{Normal Morphology}

The sperm morphological normality reduced significantly in the BUS control group compared to the normal control group $(P<0.01)$. No significant alterations were seen in $\mathrm{CRO}$ groups compared to the normal control $(P>0.05)$. Normal morphology was improved in all treated $\mathrm{CRO}$ and BUS+CRO groups significantly compared to the BUS control group $(P<0.01)$ (Table 1).

\section{Height of Germinal Layer in Seminiferous Tubules}

BUS caused a reduction in height of germinal layer than the normal group $(P<0.01)$. No significant 
modifications were detected comparing to the normal group $(P>0.05)$. The germinal layer of seminiferous tubule height in entirely treated CRO and BUS+CRO groups improved significantly compared to the BUS control group $(P<0.01)$ (Figures $\underline{1}$ and $\underline{2}$ and Table 2 ).

Table 1. Effect of BUS, CRO and CRO+BUS on reproductive parameters in male rats.

\begin{tabular}{|c|c|c|c|c|c|}
\hline Groups & $\begin{array}{l}\text { Mean of sperm } \\
\text { count }\left(10^{6}\right)\end{array}$ & $\begin{array}{l}\text { Sperm } \\
\text { progressive } \\
\text { motility }(\%)\end{array}$ & $\begin{array}{c}\text { Sperm viability } \\
(\%)\end{array}$ & $\begin{array}{c}\text { Sperm } \\
\text { morphology } \\
(\%)\end{array}$ & $\begin{array}{l}\text { Testosterone } \\
\text { (ng/mL) }\end{array}$ \\
\hline Normal control & $4.53 \pm 0.6$ & $6.6 \pm 0.16$ & $77.83 \pm 1.1$ & $83.15 \pm 3.5$ & $0.5 \pm 0.07$ \\
\hline BUS control & $2.16 \pm 0.5^{*}$ & $0.02 \pm 0.05^{*}$ & $30.03 \pm 4.4^{*}$ & $41.95 \pm 2.7^{*}$ & $0.01 \pm 0.05^{*}$ \\
\hline CRO $2 \mathrm{mg} / \mathrm{kg}$ & $4.5 \pm 0.43^{\dagger}$ & $6.83 \pm 0.9^{\dagger}$ & $85.06 \pm 5.7^{\dagger}$ & $83.95 \pm 4.5^{\dagger}$ & $0.52 \pm 0.02^{\dagger}$ \\
\hline CRO $8 \mathrm{mg} / \mathrm{kg}$ & $4.52 \pm 0.7^{\dagger}$ & $8.81 \pm 1.4^{\dagger}$ & $85.75 \pm 2.3^{\dagger}$ & $84.67 \pm 1.3^{\dagger}$ & $0.81 \pm 0.02^{\dagger}$ \\
\hline CRO $20 \mathrm{mg} / \mathrm{kg}$ & $4.69 \pm 1^{\dagger}$ & $11.83 \pm 3.07^{\dagger}$ & $89.45 \pm 2^{\dagger}$ & $85.36 \pm 2.4^{\dagger}$ & $1.12 \pm 0.04^{\dagger}$ \\
\hline $\mathrm{CRO}+\mathrm{BUS} 2 \mathrm{mg} / \mathrm{kg}$ & $2.16 \pm 0.50^{\text {II }}$ & $0.3 \pm 0.08^{\text {II }}$ & $59.25 \pm 4.8^{\mathbb{I I}}$ & $63.95 \pm 3.7^{\text {II }}$ & $0.11 \pm 0.05^{\pi}$ \\
\hline CRO + BUS $8 \mathrm{mg} / \mathrm{kg}$ & $2.6 \pm 0.7^{\mathbb{I I}}$ & $1.3 \pm 0.9^{\text {II }}$ & $63.95 \pm 2.5^{\mathbb{I I}}$ & $63.95 \pm 4.6^{\mathbb{I I}}$ & $0.23 \pm 0.02^{\mathbb{\Psi}}$ \\
\hline CRO + BUS 20mg/kg & $2.9 \pm 0.2^{\mathbb{I}}$ & $1.5 \pm 0.5^{\mathbb{I}}$ & $70.61 \pm 1.7^{\text {II }}$ & $63.95 \pm 2.1^{\text {II }}$ & $0.32 \pm 0.04^{\pi}$ \\
\hline
\end{tabular}

Data are presented as mean $\pm \mathrm{SD}$ ( $n=6$ in each group). ${ }^{*} P<0.01$ compared to the normal control group. ${ }^{\dagger} P<0.01$ compared to the BUS control group. ${ }^{\mathbb{I}} P<0.01$ compared to the BUS control group. CRO: Crocin, BUS: Busulfan.

Table 2. Effects of BUS and CRO on height of germinal layer in seminiferous tubules, MDA, and TAC levels in male rats ( $\mathbf{n}=\mathbf{8}$ for each group).

\begin{tabular}{|c|c|c|c|}
\hline Groups & MDA (nm/gKW) & TAC (mmol/mL) & $\begin{array}{c}\text { Germinal layer height } \\
\qquad(\mu \mathrm{m})\end{array}$ \\
\hline Normal control & $71.94 \pm 0.62$ & $1.09 \pm 0.02$ & $52.87 \pm 0.8$ \\
\hline BUS control & $118.13 \pm 2.64^{*}$ & $0.42 \pm 0.03^{*}$ & $23.5 \pm 2.05^{*}$ \\
\hline CRO $2 \mathrm{mg} / \mathrm{kg}$ & $66.63 \pm 3.03^{\dagger}$ & $1.12 \pm 0.07^{\dagger}$ & $51.62 \pm 3.43^{\dagger}$ \\
\hline CRO $8 \mathrm{mg} / \mathrm{kg}$ & $67.39 \pm 4.05^{\dagger}$ & $1.13 \pm 0.02^{\dagger}$ & $52.27 \pm 1.07^{\dagger}$ \\
\hline CRO $20 \mathrm{mg} / \mathrm{kg}$ & $67.40 \pm 0.93^{\dagger}$ & $1.12 \pm 0.03^{\dagger}$ & $52.25 \pm 4.33^{\dagger}$ \\
\hline CRO + BUS 2mg/kg & $96.93 \pm 3.70^{\mathbb{I l}}$ & $0.88 \pm 0.06^{\mathbb{T}}$ & $35.87 \pm 3.50^{\mathscr{I l}}$ \\
\hline CRO + BUS $8 \mathrm{mg} / \mathrm{kg}$ & $95.98 \pm 1.47^{\mathscr{I}}$ & $0.85 \pm 0.04^{\pi}$ & $36.87 \pm 3.67^{\mathscr{I}}$ \\
\hline CRO + BUS 20mg/kg & $95.38 \pm 5.23^{\mathbb{I}}$ & $0.89 \pm 0.02^{\mathscr{I}}$ & $37.35 \pm 2.18^{\text {II }}$ \\
\hline
\end{tabular}

\section{Testosterone}

BUS caused a significant diminution in testosterone level compared to the normal control group $(P<0.01)$. No significant differences were found in CRO groups than normal control group $(P>0.05)$. Furthermore, the level of testosterone hormone in all treated CRO and BUS+CRO groups improved significantly compared to the BUS control group $(P<0.01)$ (Table 1).

\section{MDA Levels}

MDA levels displayed a significant increase in BUS group than normal control group $(P<0.01)$. Also, a significant decrease in MDA levels was detected in all
CRO and CRO+BUS groups compared to the BUS control group $(P<0.01)$ while had no significant effect on levels of MDA in all CRO groups compared to the normal control group $(P>0.05)$ (Table 2).

\section{TAC Levels}

TAC levels showed a significant reduction in BUS control group comparing to normal control group $(P<0.01)$. A significant increase in TAC was found in whole CRO and CRO+BUS groups compared to the BUS control group $(P<0.01)$ while had no significant effect on TAC levels in all CRO groups compared to the normal control group $(P>0.05)$ (Table 2). 


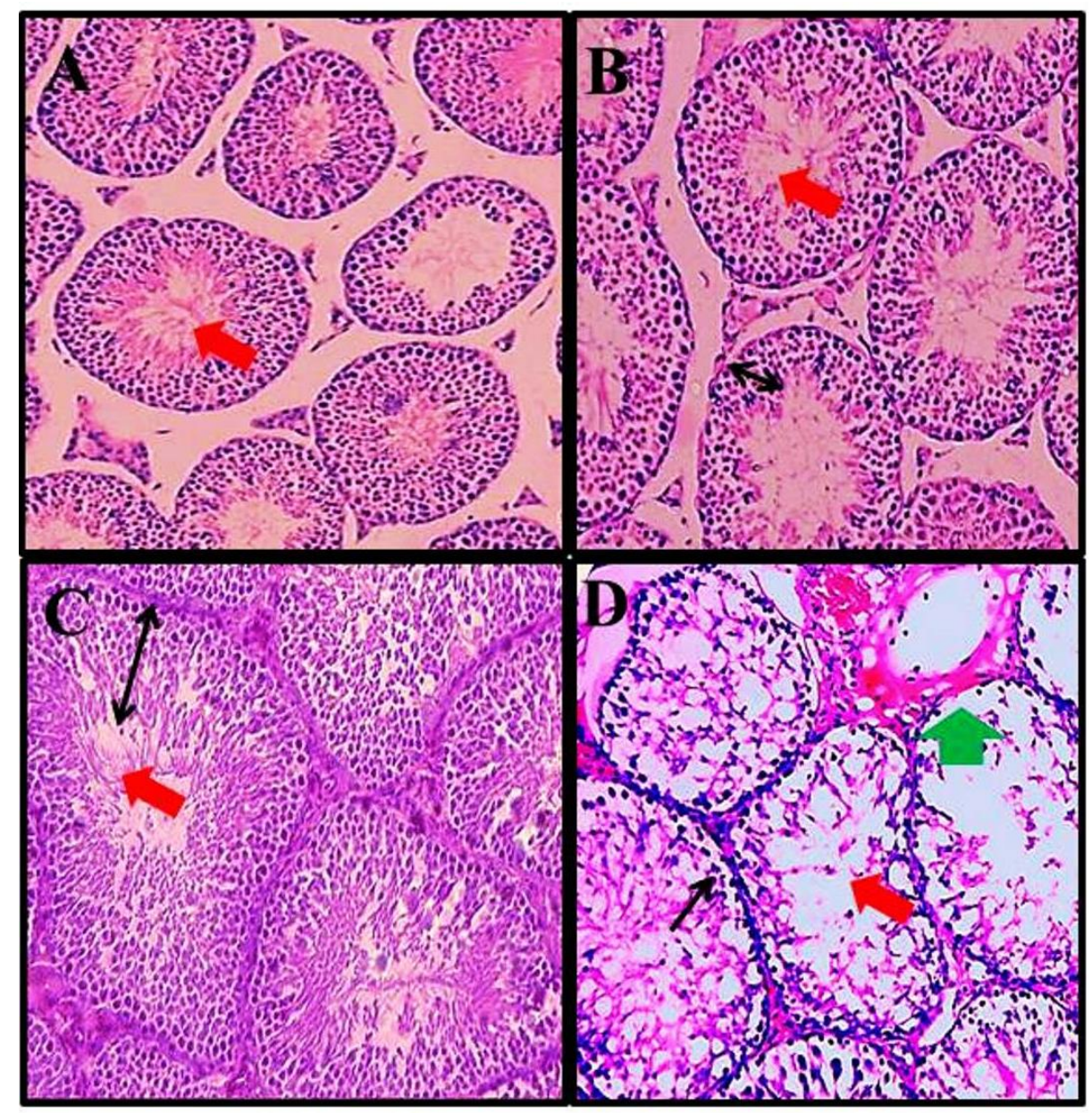

Figure 1. . Effects of BUS, CRO and CRO + BUS on seminiferous tubules (H\&E staining; 400×). Normal tubules detected in normal control group (A), CRO group (50 mg/kg) (B), and CRO + BUS groups (50 mg/kg of CRO) (C). Lumen space in abnormal conditions filled with degenerated cells, degenerated and vacuolated Leydig cells, degeneration of spermatogonial cells and release of cell debris into the lumen space, destruction of the wall of seminiferous tubules, a decrease in germinal layer of seminiferous tubules height, destruction of the cells sequence, vacuolization and reduce sperm cells density due to oxidative stress induced by BUS administration were observed in the BUS control group (D). The black arrow shows height of germinal layer, red detects sperms density, green indicates irregularities of the tubular border (destruction of the membranous structure of seminiferous tubules).

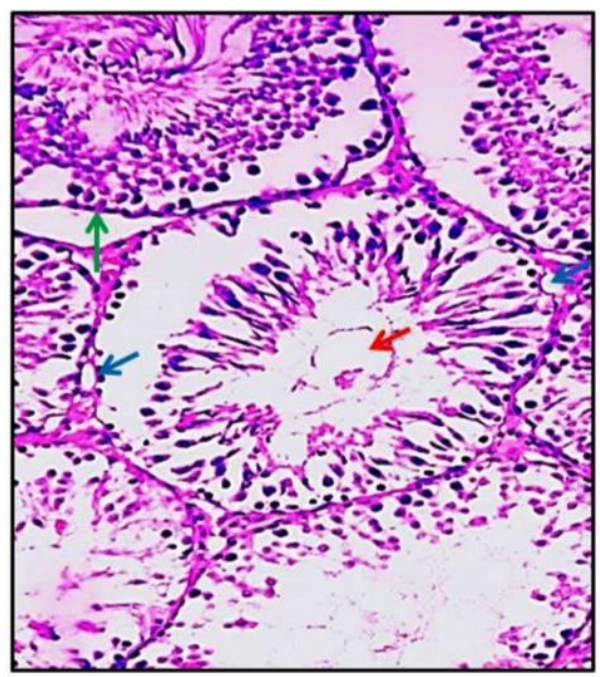

Figure 2. Histopathological changes in testicular tissue in BUS control group $(\mathrm{H \& E} ; 400 \times)$. A reduction in height, destruction, vacuolization and reduce sperm cell density were observed. Red identifies the sperm cell density, green determines irregularities in the margin of tubules, and blue detects vacuolization. BUS: Busulfan. 


\section{Discussion}

Oxidative stress as the product of chemotherapy disrupts spermatogenesis process, reduces the production of healthy spermatozoids, and decreases fertility rate (20). Thus, the administration of potential antioxidant compounds besides chemotherapy drugs dramatically increases the protective ability of cells against free radicals attack (21). According to this investigation, BUS has destructive effects on testes parenchyma, sperm parameters, oxidant-antioxidant balance, and testosterone hormone level. CRO as a phytoestrogen alleviates the adverse impacts of BUS in male reproductive system and recovers the testicular damage by reduction in MDA and lipid peroxidation levels. Besides the findings of this survey, various studies have confirmed the anti-oxidant features of CRO (12-14). Due to the lipophilic property of CRO, it may inhibit the tert-butyl-hydroperoxide-induced lipid peroxidation in sperms through Fenton reaction (13). Thus, it appears that the CRO with anti-oxidant nature inhibits the ROS production in which the levels of MDA and TAC reduces and increases, respectively. As the results showed, the CRO recovers male reproductive parameters and decreases the oxidative stress by induction of a declining trend in the MDA level. In spermatogenesis, the sperms lose a large amount of cytoplasm and deplete from cellular antioxidant agents; thus they have a higher sensitivity to increased ROS than other somatic cells (18). Cellular and organelle membrane peroxidation is considered as the first outcome of the ROS attack to the cell membrane structures (22). Antioxidants such as CRO eliminate toxins and free radicals around the cells to inhibit lipid peroxidation and to protect the cell biochemical structure (23). In the BUS control group, it is concluded that all sperm parameters reduced significantly comparing to the normal control group. All sperm parameters showed significant growth in CRO and BUS $+\mathrm{CRO}$ groups compared to the BUS control group. Spermatogenesis is a highly com-plicated process that is influenced by numerous destructive factors, the most well-known of which is oxidative stress that finally causes male infertility (24), especially by ROS accumulation (10). ROS has inhibitory effects on DNA and RNA synthesis and mitochondrial function (18). It seems that the oxidative stress generated by BUS causes arrest in cell division and anomalies in sperm differentiation, thus induces a reduction in spermatogenic lineage (25). The findings of Aitken et al. confirmed the results of the present study indicating that the oxidative stress disturbs spermatogenesis and causes defective gametes with remodeled chromatin. These conditions predispose the spermatogenesis cell line to be attacked by free radicals and leading to death of spermatogonia and spermatocytes (26). The reduction of all sperm parameters in the BUS group is related to the direct increase of oxidative stress-induced lipid peroxidation. This phenomenon alters the physiological nature of cell membrane and causes the loss of sperms transfer to epididymis (27). High levels of ROS induce mitochondrial damage and release proapoptotic proteins within the inter-membrane space. Flow of pro-apoptotic agents leads to activation of apoptosis process by following pathways; activation of caspases, reduction of adenosine triphosphate synthesis, release of more ROS, increase of intracellular calcium concentration, and mitochondria-to-cytosol calcium transfer (10). BUS by the higher expression of stimulated by Retinoic Acid 8, can induce DNA damage and cell destruction (27). Bahmanpour et al. (28) reported that the BUS administration in male Wistar rats attenuates the number of spermatogonia, spermatids, and Sertoli cells than the control group. This result approves the outcomes of our investigation. Increased levels of free radicals related to BUS administration, can impair the Sertoli cells and destroy the cytoplasmic bridges through the loss of epithelial cells (3). It seems that BUS increases the number of immature Sertoli cells and enhances the production of cytokeratin 18 in impaired spermatogenesis (29). Reduced sperm motility following BUS administration may be related to the detrimental effects of drugs on mitochondrial DNA or impairment of mitochondria as a critical organelle involved in sperm motility and adenosine triphosphate formation in energy supply (8). CRO affects some members of antioxidative enzymes (12). The antioxidant feature of CRO is related to the presence of sugar molecules with a vital role in its chemical reactivity (13). Roshankhah et al. (18) showed that the CRO administration improves sperm parameters like count, motility, and viability in diabetic rats, which are in line with the results of the present study. In fact, CRO prevents free radicals production (13). CRO can inhibit the expression of matrix metalloproteinase and proinflammatory factors such as tumor necrosis factor- $\alpha$, nuclear factor-K $\beta$, interleukin- $1 \beta$, and interleukin- 6 . It may also exert its anti-apoptotic and cytoprotective effects by suppression of caspase- 3 and tumor necrosis factor- $\alpha$ expression (30). CRO by promotion of sperm antioxidant defense system, including superoxide dismutase, glutathione peroxidase, and catalase plays a vital role in enhancement of sperm motility and viability (31). The present study indicated that the testosterone level and the germinal layer thickness were significantly reduced in BUS group. Significant growth was detected in testosterone level and germinal layer height in seminiferous tubules in all CRO and CRO+BUS groups compared to the BUS control group. Further, histological analyses showed the loss of natural form, order, and consistency of cells on the walls of seminiferous tubules and finally lead to vacuoles germination in BUS control group. Development of vacuole in the testis is the result of oxidative stress process. It seems that the BUS as an alkylating agent leads to cell destruction, DNA damage, and reduction in the thickness of the germinal layer (32). The results of Vahdati et al. (33) were in agreement with the findings of the present research, indicating that the BUS reduces the diameter of seminiferous tubules, sperm count, 
motility, epithelial thickness of seminiferous tubules, viability and finally increases the abnormal sperms. As an antioxidant, CRO not only inhibits lipid peroxidation and testicular oxidative stress but also plays a key role in the production of steroids in testis (18). Besides, CRO can deactivate the oxidative stress negative effects and enhancement of cell ability to overcome oxidative stress conditions via preventing the reduction of glutathione and increasing antioxidant capacity (34). The findings of Sefidgar et al. (35) were in line with the result of the present study, showing that the phytoestrogens like CRO bind to the testicular estrogen receptors and stimulate the spermatogenesis through strategies such as increasing the epithelial layers and diameter of seminiferous tubules and lumen.

\section{Conclusion}

The present study showed that the BUS-induced male reproductive injuries could be improved by plant antioxidants resource like CRO. Thus, it can enhance some male reproductive dysfunctions. In conclusion, the outcomes of this study demonstrated that the BUS could cause defects in male reproductive parameters by the disruption in antioxidant and defensive system. It was revealed that the $\mathrm{CRO}$ enhances the quality of spermatozoa and improves the typical morphology, sperm viability, height of germinal layer seminiferous tubules, TAC, motility, and count and also reduces the testis MDA level. CRO can be used for infertile men due to the antioxidant properties. Supplementary studies are essential to explain their precise molecular mechanism of action.

\section{Acknowledgments}

We are grateful to the Research Council of Kermanshah University of Medical Sciences (Grant No. 97305) for their financial support.

\section{Conflict of Interest}

Authors declared no conflict of interest.

\section{References}

1. Solomon R, Shvartsur R, Azab AN. The association between psychotropic drug use and fertility problems among male subjects. J Psychiat Pract. 2019; 25(1): 22-33. [DOI:10.1097/PRA.0000000000000353] [PMID]

2. Liu FJ, Dong WY, Zhao H, Shi XH, Zhang YL. Effect of molybdenum on reproductive function of male mice treated with busulfan. Theriogenology. 2019; 126: [DOI:10.1016/j.theriogenology.2018.12.002] [PMID]
3. Hakemi SG, Sharififar F, Haghpanah T, Babaee A, Eftekhar-Vaghefi SH. The effects of olive leaf extract on the testis, sperm quality and testicular germ cell apoptosis in male rats exposed to busulfan. Int J Fertil Steril. 2019; 13(1): 57-65

4. Abofoul-Azab M, Lunenfeld E, Levitas E, et al. Identification of premeiotic, meiotic, and postmeiotic cells in testicular biopsies without sperm from Sertoli cell-only syndrome patients. Int J Mol Sci. 2019; 20(3): 470-79. [DOI:10.3390/ijms20030470] [PMID] [PMCID]

5. Dehghani F, Sotoude N, Bordbar H, Panjeshahin MR, Karbalay-Doust S. The use of platelet-rich plasma (PRP) to improve structural impairment of rat testis induced by busulfan. Platelets. 2019; 30(4): 513-20. [DOI:10.1080/09537104.2018.1478400] [PMID]

6. Jalilvand N, Hosseini M, Beheshti F, EbrahimzadehBideskan A. Protective effect of PPAR $\gamma$ agonist pioglitazone, on testicular tissue and sperm parameters in hypothyroid rats. Toxin Rev. 2019; 24 : 1-10. [DOI:10.1080/15569543.2018.1564775]

7. Honaramooz A, Behboodi E, Hausler CL, et al. Depletion of endogenous germ cells in male pigs and goats in preparation for germ cell transplantation. J Androl. 2005; 26(6): 698-705. [DOI:10.2164/jandrol.05032] [PMID] [PMCID]

8. Li B, He X, Zhuang M, et al. Melatonin ameliorates busulfan-induced spermatogonial stem cell oxidative apoptosis in mouse testes. Antioxid Redox Signal. 2018; 28(5): 385-400. [DOI:10.1089/ars.2016.6792] [PMID]

9. Vafaei A, Mohammadi S, Fazel A, Soukhtanloo M, Pour AM, Beheshti F. Effects of carob (Ceratonia siliqua) on sperm quality, testicular structure, testosterone level and oxidative stress in busulfaninduced infertile mice. Pharm Sci. 2018; 24(2): 10411. [DOI:10.15171/PS.2018.16]

10. Jalili C, Kamani M, Roshankhah S, Sadeghi H, Salahshoor MR. Effect of Falcaria vulgaris extracts on sperm parameters in diabetic rats. Andrologia. 2018; 50: e13130. [DOI:10.1111/and.13130] [PMID]

11. Salahshoor MR, Haghjoo M, Roshankhah S, Makalani F, Jalili C. Effect of thymoquinone on reproductive parameter in morphine-treated male mice. Adv Biomed Res. 2018; 7: 18. [DOI:10.4103/abr.abr_69_17] [PMID] [PMCID]

12. Salahshoor MR, Khazaei M, Jalili C, Keivan M. Crocin improves damage induced by nicotine on a number of reproductive parameters in male mice. Int J Fertil Steril. 2016; 10(1): 71-78.

13. Jalili C, Tabatabaei H, Kakaberiei S, Roshankhah SH, Salahshoor MR. Protective role of crocin against nicotine-induced damages on male mice liver. Int $\mathbf{J}$ Prev Med. 2015; 6: 92. [DOI:10.4103/20087802.165203] [PMID] [PMCID]

14. Suh KS, Chon S, Jung WW, Choi EM. Crocin attenuates methylglyoxal-induced osteoclast dysfunction by regulating glyoxalase, oxidative stress, and mitochondrial function. Food Chem Toxicol. 2019; 24 124 [DOI:10.1016/j.fct.2018.12.031] [PMID] 
15. Colapietro A, Mancini A, D'Alessandro AM, Festuccia C. Crocetin and crocin from saffron in cancer chemotherapy and chemoprevention. AntiCancer Agents Med Chem. 2019; 19(1): 38-47. [DOI:10.2174/1871520619666181231112453] [PMID]

16. Dastjerdi MN, Salahshoor MR, Mardani M, et al. The apoptotic effects of sirtuin1 inhibitor on the MCF-7 and MRC-5 cell lines. Res Pharm Sci. 2013; 8(2): 79 89. [DOI:10.4103/2277-9175.108005] [PMID] [PMCID]

17. Chen Y, Tian X, Zhao C, et al. Antioxidant potential of crocins and ethanol extracts of Gardenia jasminoides Ellis and Crocus sativus L.: A relationship investigation between antioxidant activity and crocin contents. Food Chem. 2008; 109: 484-92. [DOI:10.1016/j.foodchem.2007.09.080]

18. Roshankhah S, Jalili C, Salahshoor MR. Effects of crocin on sperm parameters and seminiferous tubules in diabetic rats. Adv Biomed Res. 2019; 8: 4-11. [DOI:10.4103/abr.abr_124_18] [PMID] [PMCID]

19. Badehnoosh B, Karamali M, Zarrati M, et al The effects of probiotic supplementation on biomarkers of inflammation, oxidative stress and pregnancy outcomes in gestational diabetes. J Matern Fetal Neonatal Med. 2018; 31(9): 1128-36. [DOI:10.1080/14767058.2017.1310193] [PMID]

20. Qu N, Itoh M, Sakabe K. Effects of chemotherapy and radiotherapy on spermatogenesis: The role of testicular immunology. Int J Mol Sci. 2019; 20(4): 957-64. [DOI:10.3390/ijms20040957] [PMID] [PMCID]

21. Selvakumar E, Prahalathan C, Mythili Y, Varalakshmi P. Protective effect of dl- $\alpha$-lipoic acid in cyclophosphamide induced oxidative injury in rat testis. Reprod Toxicol. 2004; 19(2): 163-67. [DOI:10.1016/j.reprotox.2004.06.015] [PMID]

22. Salahshoor MR, Haghjoo M, Roshankhah S, Makalani F, Jalili C. Effect of thymoquinone on reproductive parameter in morphine-treated male mice. Adv Biomed Res. 2018; 7: 18-22. [DOI:10.4103/abr.abr_69_17] [PMID] [PMCID]

23. Vaez A, Mardani M, Razavi S. Impact of saffron on rat sperm membrane integrity and spermatogenesis status. Adv Biomed Res. 2014; 3: 146-52. [DOI:10.4103/2277-9175.135163] [PMID] [PMCID]

24. Potnuri AG, Allakonda L, Lahkar M. Crocin attenuates cyclophosphamide induced testicular toxicity by preserving glutathione redox system. Biomed Pharmacother. 2018; 101: 174-80. [DOI:10.1016/j.biopha.2018.02.068] [PMID]

25. Olejnik J, Suchowerska N, Herrid M, Jackson M, Hinch G, Hill J. Spermatogonia survival in young ram lambs following irradiation, Busulfan or thermal treatment. Small Rumin Res. 2018; 166: 22-27. [DOI:10.1016/j.smallrumres.2018.07.017]
26. Aitken RJ, Baker MA. Oxidative stress, sperm survival and fertility control. Mol Cell Biol. 2006; 250(1-2): 66-69. [DOI:10.1016/j.mce.2005.12.026] [PMID]

27. Moloody M, Shahrooz R, Razi M, Zarei L, Mohammadi V. The effect of CoQ10 on testicular tissue in rats treating with busulfan: Sperm quality and histological changes. Iran J Vet Med. 2018; 13(1): 29-38.

28. Bahmanpour S, Jahromi BN, Koohpeyma F, Keshavarz M, Bakhtari A. Effects of different doses and time-dependency of busulfan on testes parameters and spermatogenesis in a rat model: A quantitative stereological study. J Adv Med Sci Appl Technol. 2017; 3(3): 155-62. [DOI:10.32598/jamsat.3.3.155]

29. Bar Shira Maymon B, Marks A, Hauser R, Botchan A, Yavetz H. Sertoli cell inactivation by cytotoxic damage to the human testis after cancer chemotherapy. Fertil Steril. 2004; 81(5): 1391-94. [DOI:10.1016/i.fertnstert.2003.09.078] [PMID]

30. Park SH, An JE, Jang S, Kim JY, Lee JW, Kim HK. Gardenia jasminoides extract without crocin improved atopic dermatitis-like skin lesions via suppression of Th2-related cytokines in Dfe-induced NC/Nga mice. J Ethnopharmacol. 2019; 4: 112015112021. [DOI:10.1016/j.jep.2019.112015] [PMID]

31. Sapanidou V, Taitzoglou I, Tsakmakidis I, et al. Antioxidant effect of crocin on bovine sperm quality and in vitro fertilization. Theriogenology. 2015; 84(8): [DOI:10.1016/j.theriogenology.2015.07.005] [PMID]

32. Zhao Y, Zhang S. PGAM1 knockdown is associated with busulfan-induced hypospermatogenesis and spermatogenic cell apoptosis. Mol Med Rep. 2019; 19(4): 2497-2502. [DOI:10.3892/mmr.2019.9930] [PMID] [PMCID]

33. Vahdati A, Fathi AR, Nasimi P, Saki G. Busulfan induces apoptotic and cytotoxic effects on testis and epididymal sperm of adult male mouse following low dose treatment. Int $\mathrm{J}$ Biol. 2015; 5: 70-78. [DOI:10.12692/ijb/6.5.70-78]

34. Suh KS, Chon S, Jung WW, Choi EM. Crocin attenuates methylglyoxal-induced osteoclast dysfunction by regulating glyoxalase, oxidative stress, and mitochondrial function. Food Chem Toxicol. 2019; 124: 367-73. [DOI:10.1016/j.fct.2018.12.031] [PMID]

35. Sefidgar SM, Ahmadi-hamedani M, Javan AJ, Sani RN, Vayghan AJ. Effect of crocin on biochemical parameters, oxidative/antioxidative profiles, sperm characteristics and testicular histopathology in streptozotocin-induced diabetic rats. Avicenna J Phytomed. 2019; 9(4): 347-55. 


\section{How to Cite This Article:}

Roshankhah S, Abdolmaleki A, Jalili C, Salahshoor M R. Crocin Reduces Oxidative Stress Produced by Busulfan Administration on Fertility of Male Rats. J Adv Med Biomed Res. 2019; 27 (125) :25-33

\section{Download citation:}

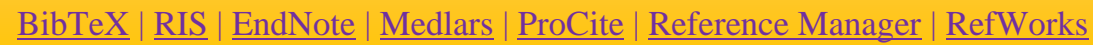

Send citation to:

9. Mendeley 2 Zotero 물efWorks $\underline{\text { RefWorks }}$ 